\title{
MENGURAI PETA KITAB-KITAB HADITS (Kajian Referensi atas Kitab-kitab Hadits)
}

\author{
Arif Wahyudi \\ (Jurusan Syariah STAIN Pamekasan, Jl Raya Panglegur Km. 04 Pamekasan \\ email: ariyos.wahyudi@yahoo.com)
}

\begin{abstract}
Abstrak
Karya di bidang hadits sangat kaya, baik dari segi kuantitas, ragam kajian maupun metodologi penyusunannya. Dengan karya yang demikian banyak, tentu tidak mudah untuk mengkaji dan mengenal seluruhnya. Faktor ini membuat sebagian pengkaji ilmu keislaman kurang tepat dalam bereferensi terhadap kitab-kitab hadits. Oleh karena itu, perlu terdapat kajian mengenai ragam dan karakteristik kitab-kitab hadits untuk memudahkan melacak maupun mereferensi pada setiap hadits yang diambil. Tulisan ini tidak mencakup seluruh kitab hadits, namun memfokuskan pada beberapa macam kitab hadits, seperti kitab-kitab induk hadits, kitabkitab syarh, kitab-kitab penghimpunan dan kitab-kitab rijal. Kitab induk hadits merupakan kitab yang ditulis mukharrij hadits dengan sanad bersambung sampai ke nabi tanpa mengutip dari kitab-kitab ulama yang lain. Kepada kitab-kitab inilah setiap penukilan hadits dirujuk. Kitab-kitab syarh hadits merupakan penjelasan terhadap kitab-kitab induk tertentu mengenai makna matn hadits maupun tentang sanad-nya. Kitab penghimpunan merupakan kumpulan hadits-hadits dari berbagai kitab induk hadits sesuai dengan tema yang diinginkan penulis kitabnya. Kitab-kitab inilah yang sering disalahartikan sebagai kitab induk hadits. Adapun kitab rijâl al-hadits membicarakan mengenai para periwayat hadits, ditujukan untuk menilai validitas hadits dari sisi sanad, baik ketersambungannya, atau cacat tidaknya seorang rawî.
\end{abstract}

Abstract
Works in $\underline{\text { Hadits field are very rich in quantity, various studies }}$
and also in their methods composition. Because of so many
works, it makes us not easy to study and know all the works.
This factor makes some reviewers of Islamic studies write the
reference less correctly with the $\underline{\text { Hadits book. Therefore, it }}$
needs a study relating the variety and characteristics of $\underline{\text { Hadits }}$ 
Arif Wahyudi

books to make it easy in looking for the reference on every Hadits taken. This article does not study all $\underline{H}$ aditts books, but it focuses on some of them, such as the main books of Hadits, syarh books, colection books and rijâl books. The main books Hadits are those which are written by Hadîts mukharrij with sanad continued to the prophet without quoting another ulamá books. Every quotation of $\underline{\text { Hadits }}$ has referred to those books. Syarh Hadits books are the explanation to certain main books about the meaning of matn $\underline{\text { Hadits }}$ and its sanad. The colection

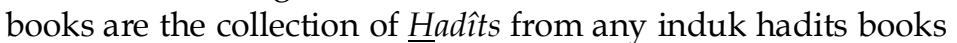
suitable with the theme wanted by their writers. These books are often misinterpreted as the main book of Hadits. While the books of rijâl al- $\underline{H}$ adits talk about $\underline{H}$ adîts historians, purposed to assess the Hadits validity of sanad perspective, both its connection or whether the rawi is invalid or not.

\section{Kata-kata Kunci}

Matn, syarh, rijâl, sanad, rawî.

\section{Pendahuluan}

Berbeda dengan al-Qur’an yang keseluruhannya diriwayatkan dengan mutawâtir (qath iyat al-tsubût), mayoritas Hadits merupakan khabar ahad yang hanya menghasilkan hal yang bersifat dugaan (zhanniyat al-tsubût). Oleh karena itu, usaha untuk menjaga Hadits para ulamâ' membuat karya dalam bidang Hadits yang sangat kaya, bahkan terkadang satu ulamâ' memiliki puluhan karya di bidang ini. Ditambah pula metode dan sistematika penyusunan yang digunakan bermacam-macam dan berbeda antara satu dengan yang lain.

Dengan karya yang demikian banyak, tentu tidak mudah untuk mengkaji dan mengenal seluruhnya, apalagi dilakukan oleh orang yang tidak secara khusus mendalami ilmu-ilmu agama. Padahal, Hadits adalah sumber hukum dari ajaran Islam, sehingga pembahas kajian-kajian keIslaman pasti membutuhkan Hadits sebagai argumentasi. Faktor banyaknya karya di bidang Hadits ini seringkali membuat pengkaji keilmuan Islam kurang tepat dalam mereferensi kepada Hadits, terutama dalam karya ilmiah, baik skripsi maupun tesis, yang merupakan tugas akhir bagi calon sarjana ilmu- 
ilmu keislaman. ${ }^{1}$ Bahkan, tampaknya sebagian lainnya lebih memilih tidak mencantumkan Hadits-Hadits yang seharusnya dicantumkan dalam kajiannya demi menghindari kesalahan-kesalahan yang mungkin dilakukannya. Oleh karena itu, perlu terdapat kajian mengenai ragam dan karakteristik kitab-kitab Hadits untuk memudahkan melacak maupun mereferensi pada setiap Hadits yang dinukil.

\section{Kitab-kitab Matn Hadits: Kitab Induk Hadits}

Ketika disebut kitab matn Hadits, maka secara otomatis yang dimaksud adalah kitab yang disusun oleh mukharrij (kolektor Hadits), berisi matn Hadits dan sanad-nya tersambung mulai dari yang terendah, yaitu kolektor, sampai kepada nabi Muhammad saw. Kitabkitab inilah yang disebut sebagai sumber pokok Hadits, karena disusun secara independen tanpa mengutip dari kitab ulamâ' yang lebih dulu. Ketika mengutip matn Hadits, maka kepada kitab-kitab yang ditulis mukharrij itulah seharusnya bereferensi. Berikut ini adalah di antara kitab-kitab induk Hadits sesuai kronologis dan jenisnya.

Pertama, Kitab-kitab al-Muwattha dan al-Musannaf.2 Di antara kitab dengan metode ini yang terkenal ialah kitab al-Muwattha' yang disusun oleh Imâm Mâlik ibn Anas Abû`Abdullâh al-Ashbahi (93-179 $\mathrm{H})^{3}$. Kitab ini terdiri atas 2 juz dan $61 \mathrm{bab}$, dimulai dari pembahasan

\footnotetext{
${ }^{1}$ Contoh skripsi dengan judul Nyare Dhina dalam Penentuan Hari Pernikahan Perspektif Hukum Islam di Desa Larangan Badung Kecamatan Palengaan Kabupaten Pamekasan,

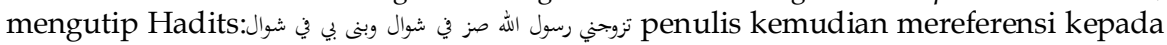
Mawlanâ Muhammad Zakariyâ, Fadiliah A'mal, padahal kitab tersebut dikenal dengan kitab himpunan Hadits, bukan kitab induk Hadits di mana seharusnya setiap penukilan Hadits mereferensi kepadanya. Banyak lagi contoh skripsi yang lain dengan model pereferensian yang sama.

2 Al-Muwattha' atau al-Mushannaf ini merupakan kitab yang disusun berdasarkan bab-bab figh. Pada saat itu, konsentrasi utama para ulamâ' adalah bagaimana merekam ajaran-ajaran Islam yang tidak terdapat dalam al-Qur`an, sehingga penulisan yang mereka lakukan terkadang tidak terlalu memperhatikan metode penulisan sebuah kitab Hadits dan masih mencampur Hadits dengan perkataan sahabat, tâbi'în bahkan perkataan penulis sendiri. Lihat Yûsuf `Abd al-Rahmân, ' $\mathrm{Ilm}$

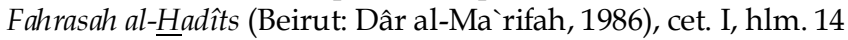

3 Muhammad al-Dzahabî, Siyar A 'âm al-Nubalâ, juz VIII (Beirut: Mu'assasah alRisâlah, 1413 H), hlm. 48
} 
Arif Wahyudi

tentang waktu shalat dan diakhiri dengan pembahasan tentang namanama nabi Muhammad saw. ${ }^{4}$ Terjadi perbedaan pandangan di kalangan ulamâ' ketika dihadapkan pada pertanyaan apakah almuwattha' merupakan kitab figh atau kitab Hadits. Abû Zahwu berpendapat bahwa al-Muwattha' bukan hanya kitab figh namun kitab Hadits sekaligus, karena sistematika penulisan yang menggunakan bab-bab figh tidak hanya monopoli Imâm Mâlik, namun juga digunakan oleh para penyusun kitab Hadits lainnya. Di samping itu, Imâm Mâlik di beberapa tempat dalam kitabnya juga memberikan komentar dan kritik terhadap sebuah riwayat Hadits. ${ }^{5}$ Dalam penyusunan kitabnya, Imâm Mâlik lazim melakukan beberapa tahapan tertentu, diawali dengan menuliskan Hadits, lalu menyebutkan fatwa para sahabat, fatwa tâbi în, ijmâa ulamâ' Madinah dan acapkali ditutup dengan pendapatnya sendiri. Tahapan-tahapan itu tidak selalu ada dalam setiap pembahasan, namun menyebutkan Hadits nabi merupakan acuan pertama yang dilakukan Imâm Mâlik. ${ }^{6}$

Kitab-kitab jenis ini terdapat hampir di tiap kota besar saat itu, seperti al-Mushannaf karya Abd al-Mâlik ibn Abd al-Azîz al-Bashrî (w. $150 \mathrm{H}$ ) di Mekkah, al-Muwattha' di Madinah, al-Mushannaf karya al-Rabi ibn al-Shâbih di Bashrah, dan lain-lain. ${ }^{7}$

Kedua, Kitab-kitab al-Musnad. ${ }^{8}$ Orang pertama yang menyusun Hadits dengan konsep ini adalah Abû Dawûd Sulaymân ibn al-Jarrad al-Tayyalasi (133-204 H). ${ }^{9}$

\footnotetext{
4 Berdasarkan daftar isi Mâlik bin Anas, al-Muwattha', (pentahqiq) Muhammad Mushtafâ al-A`zhamî (ttp: Muassasah Zaid ibn Sulthân al-Nahyân, 2004).

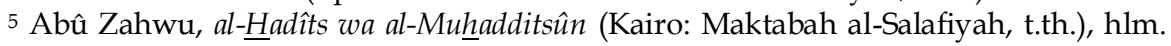
256

${ }^{6}$ Dosen Tafsir Hadits IAIN Sunan Kalijaga Yogyakarta, Studi Kitab Hadis (Yogyakarta: Teras, 2003), hlm. 14

7 Muh. Zuhri, Hadits Nabi: Telaah Historis dan Metodologis (Yogyakarta: PT. Tiara Wacana, t.t.), hlm. 58-59

8 Metode musnad ialah membuat bab sesuai rawî tertingginya yaitu sahabat. Berbeda dengan kitab-kitab al-Muwattha' yang masih mencampur Hadits dengan perkataan sahabat dan yang lainnya, kitab-kitab musnad hanya memasukkan Hadits nabi saja. Lihat Subhî Shâlih, Membahas Imu-Ilmu Hadits, terj. Tim Pustaka Firdaus (Jakarta: Pustaka Firdaus, 2009), hlm. 59

${ }^{9}$ Ahmad bin Alî Abû Bakr Khatîb al-Baghdâdî, Târîkh al-Baghdâdî, juz IV (Beirut: Dâr al-Kutub al-'Ilmiyah, tth.), hlm. 412-422
} 
Kitab sejenis yang dianggap paling luas dan memadai adalah Musnad Ahmad bin Hanbal, yang disusun oleh Ahmad ibn Muhammad ibn Hanbal bin Hilâl (164-241 H). Kitab ini berisi 40.000 Hadits, diulang-ulang sekitar 10.000. Putranya yang bernama Abdullâh menambahkan sekitar 10.000 Hadits, demikian pula rawî yang meriwayatkan dari Abdullâh, yaitu Ja ‘far al-Qathi`i, memberikan beberapa tambahan di dalamnya. Seperti diketahui, bahwa Ahmad ibn Hanbal telah terlebih dahulu meninggal dunia sebelum memperbaikinya. Oleh karena itu, yang berperan dalam mengurutkan kitab Musnad itu adalah anaknya, Abdullâh. Sedangkan yang mengurutkan Musnad berdasarkan huruf hija iyah adalah Abû Bakr Muhammad ibn Abdillâh al-Muqaddasi. ${ }^{10}$ Karena sistematika yang dipakai adalah Musnad, maka pencarian Hadits dalam kitab ini harus berdasarkan nama sahabat yang meriwayatkan, dimulai dari Musnad Abû Bakr dan diakhiri dengan Musnad Fâthimah bint Abî Jaysy. ${ }^{11}$

Kitab-kitab jenis ini, selain karya Ahmad bin Hanbal adalah Musnad Abû Hanîfah, Musnad Ishaq bin Rahawiyah, Musnad alBazzar, Musnad al-Humaydi, dan lain sebagainya. ${ }^{12}$

Ketiga, kitab-kitab al-Juz'u. Dalam istilah ahli Hadits, al-Juz'u adalah kitab yang disusun dengan cara mengumpulkan HaditsHadits yang mempunyai tema sama dengan konsep yang sederhana, atau kitab-kitab yang sebenarnya tidak ditulis secara khusus sebagai kitab Hadits. Misalnya, kitab al-Jihâd dan al-Zuhud karya Ibn alMubârâk, Fadhâ'il al-Qur'ân dan al-Umm karya al-Syâfi'î, Tafsîr alThabâri dan Târîkh al-Thâbari karya Thabâri, dan lain-lain. ${ }^{13}$ Kitab-kitab ini meskipun tidak ditulis secara khusus sebagai kitab hadis, namun Hadits-Hadits yang terdapat dalam kitab al-Juz'u, seluruhnya diriwayatkan oleh penulisnya bersambung kepada nabi tanpa menukil dari karya orang lain. Sehingga, kitab-kitab itu pun layak disebut sebagai referensi induk Hadits.

10 Shâlih, Membahas Imu-Ilmu Hadits, hlm. 364

11 Lihat daftar isi Ahmad bin Hanbal, Musnad Ahmad (Kairo: Muassasah Qurthubah, tth.)

12 CD al-Maktabah al-Alfiyah li al-Sunnah al-Nabawiyah (Yordania: Markaz al-Turâts, 1999)

13 `Abd al-Rahmân, 'Ilm Fahrasah al-Hadîts, hlm. 15 
Arif Wahyudi

Keempat, kitab-kitab al-Shahîh. . $^{14}$ Ulamâ' yang menjadi pelopor penulisan jenis ini adalah Muhammad Ismâ'il al-Bukhârî (194-256 H)

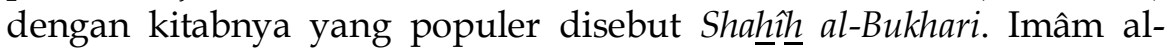
Bukhârî menulis kitab Shahı̂h-nya selama 16 tahun dan merupakan hasil seleksi dari sekitar 600.000 Hadits. Setiap kali dia ingin

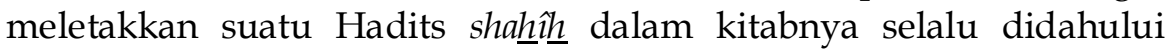
dengan bersuci dan shalat dua rakaat. ${ }^{15}$ Al-Bukhârî hanya menulis Hadits dalam kitabnya dari kelompok periwayat tingkat pertama dan sedikit dari tingkat kedua, yaitu yang memiliki sifat âdil dan kuat hafalan, teliti, jujur, dan lama dalam berguru. Tingkat kedua memiliki kriteria sama dengan yang pertama, namun tidak lama dalam berguru. ${ }^{16}$

Penyusunan yang dilakukan al-Bukhârî kemudian diikuti oleh

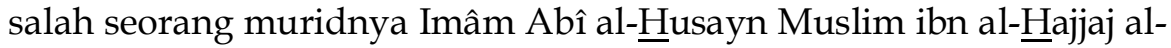
Qusyayri al-Naysaburi (206-261 H) dengan kitabnya Shahîh Muslim. Kitab ini menggunakan sistematika jâmi sama dengan shahîh alBukhârî. Dalam muqaddimah-nya Muslim mengklasifikasikan Hadits menjadi tiga macam, yakni Hadits yang diriwayatkan oleh para periwayat yang 'âdil dan dlâbit, diriwayatkan oleh para periwayat yang tidak diketahui keadaannya (mastûr) dan hafalannya biasa-biasa saja, diriwayatkan oleh periwayat yang lemah hafalannya dan Haditsnya ditinggalkan orang. Dari kategori di atas, apabila Muslim telah meriwayatkan kategori pertama beliau selalu menyertakan kategori kedua, sedang kategori ketiga dia tidak menggunakannya. ${ }^{17}$ Dua kitab ini (al-Bukhârî dan Muslim), menurut para ulamâ' adalah kitab yang paling shahîh $\underline{h}$ setelah al-Qur`an, karena syarat yang digunakan mereka demikian ketat. ${ }^{18}$ Metode ini setelah itu diikuti oleh beberapa ulamâ' yang menyusun kitabnya berdasarkan syarat al-

14 Metode shahîh ialah metode penulisan kitab Hadits berdasarkan kualitas keshahihan Hadits, cakupan pembabannya menggunakan tekhnik al-jâmi', yaitu berusaha mencakup seluruh kajian keislaman, dimulai dari kitab al-îmân dan diakhiri dengan kitab al-tawhîd.

15 Al-Dzahabî, Siyar A 'lâm al-Nubalâ, juz. XVI, hlm. 402

${ }^{16}$ Ibn Hajar al-`Asqalânî, Hâdi al-Syâri', juz I (Kairo: tnp, t.t.), hlm. 6

${ }^{17}$ Muslim, Shahîh Muslim, juz I (Beirut: Dâr al-Fikr, 1988), hlm. 3-8

18 Muhammad 'Abd al-Azîz al-Khûlî, Miftah al-Sunnah wa al-Funûn al-Hadîts (Beirut: Dâr al-Kutub al-'Ilmiyah, 1980), hlm. 47 
Bukhârî dan Muslim, di antaranya Shahîh Abû 'Awânah, Shahîh ibn Khuzaymah (w. 311 H), dan Shahîh ibn Hibbân (w. 254 H). ${ }^{19}$

Kelima, kitab-kitab al-Sunan..$^{20}$ Di antara kitab-kitab jenis ini adalah Sunan Abû Dawûd yang ditulis oleh Abû Dawûd bin Sulaymân al-Sijistan (202-275 H), Sunan al-Tirmidzi karya Abû 'Isâ Muhammad ibn 'Isâ ibn Sawrah al-Tirmidzi (209-279 H), Sunan alNasa $i$ (al-Mujtabâ) oleh Aḥmad ibn Syu’ayb ibn Alî ibn Sinan ibn Bah̆r alias Abû Abd al-Rahman al-Nasa `i (215-303 H), Sunan ibn Mâjah, dan lain-lain. Pada era ini, istilah-istilah baru yang berdasarkan pada klasifikasi kualitas Hadits bermunculan, di antaranya Hadits hasan. Istilah ini dimunculkan oleh al-Tirmidzî, sebelumnya ulamâ' hanya membagi Hadits kepada dua kategori yakni, Hadits shah $\underline{i h} \underline{\text { dan }}$ dla ${ }^{\imath} \hat{f} .{ }^{21}$ Karena kitab al-Tirmidzî banyak memuat Hadits hasan, maka kitab ini populer pula dengan sebutan kitab Hadits hasan.

Keenam, kitab-kitab al-Mustadrâk. ${ }^{22} \mathrm{D}$ iantara kitab jenis ini adalah al-Mustadrâk karya Muhammad ibn Abdullâh al-Hakîm alNaysabûrî. Dengan sistematika penyusunan jami', kitab ini merupakan salah satu yang paling terkenal dalam jenisnya. ${ }^{23}$ Terdapat pula al-Mustadrâk karya Abû Dzâr dan karya al-Daraquthnî.

Ketujuh, kitab-kitab al-Mustakhraj. ${ }^{24}$ Konsep penyusunan ini lazim digunakan pada abad ke-4 $\mathrm{H}$ dan abad ke-5 H. Di antara kitab yang disusun dengan konsep ini adalah Mustakhraj Abî `Awanah `Alâ Muslim, Mustakhraj al-Ismâ'ili 'alâ al-Bukhârî, dan lain lain.

\footnotetext{
${ }_{19}$ Muh. Zuhri, Hadits Nabi, hlm. 61

${ }^{20}$ Metode sunan adalah penulisan kitab Hadits dengan menggunakan bab-bab figh. Ibid., hlm. 63

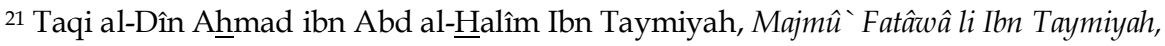
juz I (t.tp: Dâr al-Arabiyah, t.t.), hlm. 252

22 Metode Mustadrak adalah upaya untuk menghimpun Hadits-Hadits shahîh yang tidak ter-cover dalam kitab Hadits shahîh lainnya dan kitab shahîh al-Bukhârî dan Muslim.

${ }^{23}$ Dari berbagai tela'ah, al-Hâkim, al-Mustadrak Alâ al-Shahlihain, (pentahqiq) Mustafâ Abd al-Qadir `Athâ(Beirut: Dâr al-Kutub al-'Ilmiyah, 1990).

${ }^{24}$ Metode Mustakhraj adalah penyusunan kitab Hadits dengan mengambil dari kitab tertentu namun mengambil jalur sanad yang berbeda, penyusun kitab menempuh sanad lewat gurunya namun guru tersebut memiliki sanad yang sama dengan sanad penyusun Hadits yang di-takhrij atau kedua guru itu bertemu pada sanad di atasnya. Lihat `Abd al-Rahmân, 'Ilm Fahrasah al-Hadîts, hlm. 16
} 
Arif Wahyudi

Abad ke-5 H merupakan akhir dari era kodifikasi Hadits. Setelah era tersebut, sumber asli dari kitab-kitab Hadits serta sanad yang mu 'tabar relatif tidak terdapat lagi. Bahkan menurut al-Bayhâqî, para ulamâ' menolak mengambil Hadits selain dari kitab para ulamâ' lima abad pertama. Dalam terminologi ahli Hadits, karya yang lahir setelah abad ke-5 H lazim disebut "referensi baru". ${ }^{25}$

Sebenarnya, mereferensi kepada kitab-kitab Hadits induk di atas bukanlah hal yang sulit, kalau yang di-nukil adalah Hadits riwayat al-Bukhârî, maka rujukannya adalah kitab Shahîh al-Bukhârî. Pelacakannya pun tinggal melihat kepada bab-bab dalam kitab sesuai yang dibutuhkan, karena dalam penulisan Hadits, para mukharrij telah mengelompokkan Hadits sesuai dengan tema-tema tertentu. Kalau pun masih ada kesulitan, para ulamâ' yang lain juga telah memaparkan teknik-teknik takhrij tertentu yang langsung memberitahukan di lokasi kitab Hadits, mana Hadits yang dilacak dapat ditemukan.

Kedelapan, kitab-kitab penghimpunan. Setelah abad ke-5, alur penyusunan Hadits berubah dalam sistematika kajiannya. Dari penyusunan Hadits secara independen, yaitu ber-sanad dari penyusunnya bersambung sampai ke nabi saw. kepada studi dan penelitian Hadits cenderung bertumpu pada usaha mengelaborasi karya-karya yang dihasilkan ulamâ' lima abad pertama. Mulai mensyarh, menyatukan beberapa kitab Hadits, dan menghimpun HaditsHadits dari kitab-kitab Hadits induk sesuai tema, seperti menghimpun Hadits-Hadits hukum yang dilakukan oleh Ibn Hajar (773-852 H) dengan kitabnya Bulugh al-Marâm. Penghimpunan Hadits berdasar tema juga dilakukan oleh Imâm al-Nawâwî (631-676 H) dalam karyanya Riyâdh al-Shâlihîin yang menghimpun Hadits-Hadits tentang keutamaan-keutamaan amal.

Kitab-kitab jenis ini berbeda dengan metode al-Juz'u, sebagaimana yang telah dibahas sebelumnya. Penyusunan kitab-kitab penghimpunan ini biasanya menggunakan sistematika yang baik, sehingga sangat bermanfaat dan memudahkan bagi para pengkaji dalam tema-tema tertentu. Namun, karena kemudahan itu membuat kitab-kitab jenis penghimpunan ini sering dianggap sebagai kitab Hadits oleh sebagian pengkaji, sehingga tak jarang setiap pengutipan

25 Ibid., hlm. 17 
Hadits dalam karyanya selalu bereferensi ke kitab jenis ini. Padahal, kitab-kitab ini bukanlah kitab-kitab induk Hadits dan tidak ubahnya seperti kumpulan Hadits yang dilakukan oleh ulamâ' kontemporer, semisal yang ditulis Mawlanâ Muhammad Zakariya, Fadhîlat al-A ‘mâl, al-Hidâyat al-Tarbawiyah fí al-Hayâh al-Ijtimầiyah, Kumpulan Ayat dan Hadits tentang Pendidikan yang disusun beberapa dosen STAIN Pamekasan, dan lain-lain.

Kesembilan, kitab-kitab Syark. Makin luasnya wilayah Islam menunjang terjadinya akulturasi budaya yang berakibat pula pada perbendaharaan bahasa Arab yang makin menipis. Bahasa nabi yang lugas serta memiliki sastra yang tinggi, membuatnya sulit untuk dipahami oleh generasi yang hidup jauh setelah era kenabian. Oleh karenanya, merujuk kepada kitab syarh dalam mengkaji Hadits seperti menjadi ritual wajib dan tidak terelakkan.

Di antara kitab-kitab syarh tersebut adalah Syarh Muwattha' Mâlik, Tanwîr al-ㅍawâlik karya Abd al-Raḩmân ibn Abî Bakar al-Suyûthî (849-911 H). Kitab ini menjelaskan mufradat pada matn yang dianggap sulit dipahami, di dalamnya penulis sesekali menjelaskan tentang kondisi sanad dan berusaha untuk mengkomparasikan dengan jalur sanad berbeda dari mukharrij lain. ${ }^{26}$

Syarh lain dari al-Muwattha' di antaranya adalah al-Tamhî̀ limâ fí al-Muwattha'min al-Ma ânî wa al-Masânid karya Abû Umar bin Abd al-Bârr, Syarh al-Ta'lîq al-Mumajjad 'alâ al-Muwattha' karya al-Laknawi al-Hindi, dan lain-lain sampai kira-kira 8 kitab syarh.

Syarh Shahih al-Bukhârî, dari sekian kitab Hadits yang ada, kitab ini adalah yang terbanyak di-syarh oleh para ulamâ'. Jumlahnya menurut pengarang kitab Kasyf al-Zhunun ada 82 syarh. ${ }^{27}$ Di antara

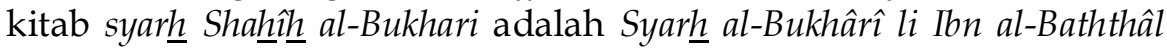

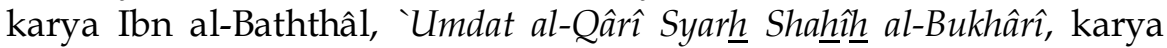
Badr al-Dîn al-'Aynî al-Hanafî dan yang paling populer dari syarh alBukhârî karya Ibn Hajar al-'Asqalâni Fath al-Bârî. Dapat dikatakan Fath al-Bârî karya Ibn Hajar al-'Asqalâni merupakan salah satu yang paling menonjol di antara syarh-syarh tersebut. Banyak hal yang dijelaskan Ibn Hajar dalam syarh-nya, dimulai dari penjelasan lafazh,

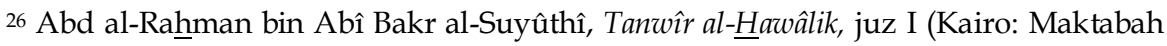
al-Tijâriyah Kubrâ, 1969), hlm. 36

27 Sebagaimana dikutip Shâlih, Membahas Imu-Ilmu Hadits, hlm. 365 
Arif Wahyudi

maksud Hadits, sanad bahkan dia mengembalikan ketersambungan Hadits-Hadits al-Bukhârî yang dianggap sebagian orang mu`allaq maupun mawqûf. 28

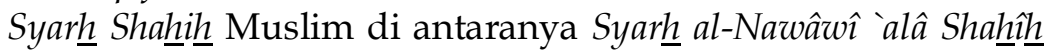
al-Muslim karya Abû Zakariya Yahya bin Syaraf al-Nawâwî (631-676 H). Dalam syarh-nya, Imâm Nawâwî menjelaskan tentang pokokpokok hukum yang terkandung dalam Hadits, adab, zuhud, kaidahkaidah syara', makna lafazh, rawî yang menggunakan nama alias, kaidah-kaidah ilmu Hadits dan berusaha mencari titik temu antara dua Hadits yang secara zhahir kelihatan bertentangan. ${ }^{29}$ Kemudian, al-

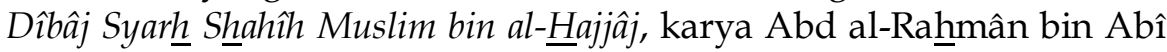
Bakr al-Suyûthî, dan lain-lain. Sebagaimana disebutkan di atas bahwa seluruh kitab Hadits yang mu tamad telah ada syarh-nya bahkan terkadang memiliki syarh lebih dari satu, di antara kitab-kitab syarh bagi empat sunan yang menonjol, ialah 'Awn al-Ma`bûd karya

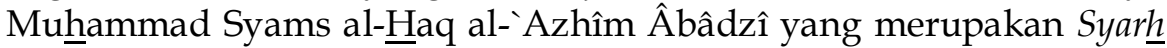
Sunan Abû Dawûd, Tuhfah al-Ahwadzî Syarh Sunan al-Tirmidzi karya Muhammad bin `Abd al-Rahmân ibn Abd al-Rahîm al-Mubârakfûrî (1283-1353 H), Syarh Sunan al-Nasâ'i karya Imâm al-Sandiy, Syarh Sunan Ibn Mâjah karya al-Sandiy.

Kesepuluh, Kitab-kitab Rijâl al-Hadîts. Telah menjadi maklum, bahwa setiap Hadits memuat dua bagian, yakni isnâd atau transmisi (mata rantai rawî) dan matn (teks Hadits). Kedua bagian ini sama pentingnya bagi ahli Hadits. Apabila sanad merupakan hasil rekaman perkataan, perbuatan, dan persetujuan nabi, maka sanad adalah fondasi dari kebenaran adanya matn. Suatu Hadits dianggap valid dari sisi sanad, apabila sanad-nya bersambung kepada nabi, tidak ada 'illah, tidak syâdz, dan diriwayatkan oleh orang-orang yang memiliki kapabilitas dari sisi intelektual dan moral. Oleh karena itu, dalam studi isnâd diperlukan pengetahuan tentang para periwayat Hadits dari sahabat, tâbîîn, dan seterusnya, baik perihal masa kehidupan mereka, pekerjaan, karakter pribadi, bahkan penilaian para ulamâ' bagi setiap rawî dan hal itulah yang disebut dengan ilmu rijâl al-hadîts.

28 Ibn ㅂajar al-`Asqalânî, Muqaddimah Fath al-Bârî (Beirut: Dâr al-Ma`rifah, 1980), hlm.

${ }^{29}$ Abû Zakariya Yahyâ bin Syaraf al-Nawâwî, Syarh al-Nawââî 'Ala Shahîh Muslim, juz I (Beirut: Dâr Ihyâ' al-Turâts al-'Arabî, tth.), hlm. 5 
Mengingat urgensi sanad, sudah dapat dipastikan kajian mengenai rijâl-nya sangat beragam dengan karakteristik dan metodologi yang berbeda-beda. Usaha untuk mengelaborasi karyakarya yang telah ada sebelumnya merupakan salah satu ciri menarik pula dalam kajian rijâl ini, seperti meringkas lalu meringkas lagi, menjadikan syair teori-teori tentang rijâl, dan lain-lain. Tak heran kalau kemudian merujuk ke kitab-kitab ini tidak mudah, bahkan kadang tersesat dengan mereferensi kepada beberapa kitab untuk satu kutipan, padahal hakikatnya kitab-kitab tersebut merupakan satu kitab. Mengetahui klasifikasi dan karakteristik kitab-kitab rijâl, dapat memberi pemahaman tentang cara merujuk dan berangkat dari mana untuk melacak biografi para periwayat yang dikaji, komentar kritikus, dari generasi apa (thabaqât) dan berasal dari mana serta pernah pergi kemana saja. Karena, mengenal hal-hal tersebut adalah pijakan, untuk memberi penilaian tentang ke-tsiqah-an para periwayat dan ketersambungan sanad suatu riwayat. Bila dicermati kajian tentang rijâl al-hadîts setidaknya dibagi ke dalam beberapa kategori berikut ini: 30

\section{Kitab-kitab Rijâl al-Âmmah}

Kitab Rijâl al-Âmmah adalah kitab yang memuat tentang biografi para rawî Hadits secara umum, tidak dikhususkan hanya pada rawî yang dianggap tsiqah maupun dla îf dan tidak pula dikhususkan pada rawî dari kitab-kitab Hadits tertentu. Contoh dari kitab jenis ini adalah al-Târikh al-Kabîr karya Imâm al-Bukhârî (w. 256 H). Kitab ini ditulis al-Bukhârî di samping makam nabi dan merupakan kitab yang luar biasa pada zamannya serta mendapat banyak pujian dari para ulamâ'. Dari telaah yang penulis lakukan, kitab ini disusun berdasarkan urutan abjad hija'iyah yang meliputi sahabat, tâbi'în dan seterusnya. Al-Bukhârî memaparkan informasi para rawî dalam kitabnya dengan metode riwayat (memakai sanad) seperti halnya Hadits, namun terkadang dalam beberapa penyebutan rawî, tidak menggunakan sanad.

Informasi yang diberikan al-Bukhârî dalam kitabnya meliputi beberapa hal sebagaimana berikut ini: Pertama, memberikan penilaian terhadap rawî, seperti:

30 Al-Dzahabî, al-Mughnî, Maktabah al-Alfiyah li al-Sunnah al-Nabawiyah (Ammân: Markaz al-Turâts li Abhâs al-Hâsib al-Âlî, 1999) 
Arif Wahyudi

محمد بن حجر عن الزهري، مرسل. 31

Penilaian terhadap para rawî tidak secara reguler dilakukan oleh al-Bukhârî, namun hanya terjadi sekali-kali, sehingga pengguna kitab ini akan sedikit kesulitan apabila tujuannya ingin mengetahui kualitas dari seorang rawî.

Kedua, menyebutkan tahun wafat

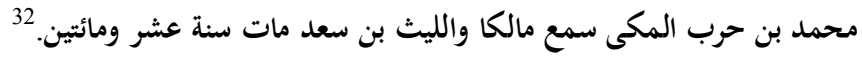

Sebagaimana "penilaian" penyebutan tahun wafat rawî, juga tidak selalu tercantum dalam kitab ini. Seringkali pula penyebutan tahun wafat tidak disertai dengan penilaian terhadap rawî.

Ketiga, Memaparkan nama rawî sekaligus dengan Haditsnya.

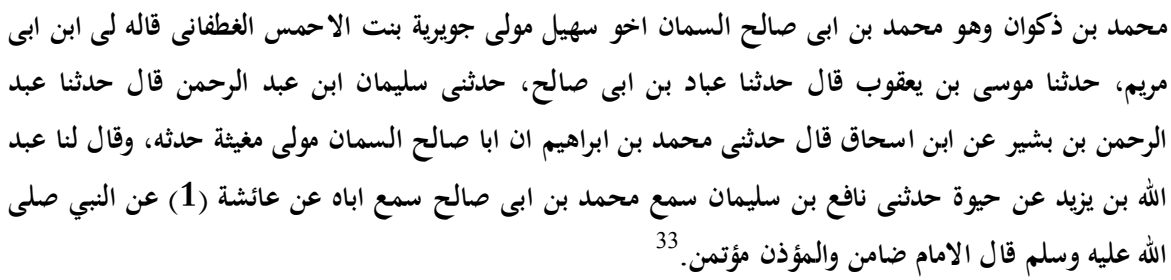

Kitab-kitab lain yang termasuk dalam kitab Rijâl al-Âmmah, di antaranya, adalah al-Târîkh al-Shaghîr karya al-Bukhârî (w. $256 \mathrm{H})$, al-Asmấ al-Mufradah karya Ahmad ibn Harûn al-Bardîhî (w. $301 \mathrm{H}$ ), al-Jarh wa Ta dîl karya Abd al-Raḩmân bin Abî Hâtim (w. 327 H), alKunâ karya al-Bukhârî (w. $256 \mathrm{H}$ ), memuat informasi tentang rawî yang menggunakan kunyah, kitab ini merupakan bagian dari Tarîkh alKabîr yang juga merupakan karya al-Bukhârî. ${ }^{34}$ Kitab lainnya ialah alKunâ wa al-Asmấ karya Muslim (w.261 H) yang juga memuat informasi rawî yang menggunakan nama kunyah. Misalnya, Abû Idrîs, rawî yang menggunakan kunyah tersebut teridentifikasi sebanyak enam orang, lalu Muslim menjelaskan nama satu persatu dari kunyah Abû Idrîs. Sudah menjadi maklum bahwa persamaan nama, kunyah

31 Al-Bukhârî, Târîkh al-Kabîr, juz I: http://www.alsunnah.com, Maktabah alSyâmilah terbitan ke-II, http://www.shamela.ws, hlm. 69

32 Ibid.

33 Al-Bukhârî, Târîkh al-Kabîr, juz 1, hlm. 78

${ }^{34}$ Al-Bukhârî, al-Kunâ li al-Bukhârî, juz I (Beirut: Dâr al-Fikr, t.t.), hlm. 1 
maupun laqab dapat terlacak salah satunya dari guru rawî tersebut, dan inilah yang dilakukan oleh Muslim dalam kitabnya. ${ }^{35}$

\section{Kitab-kitab Rijâl al-Khâsh ${ }^{36}$}

Kitab rijâl al-tsiqât adalah kitab yang khusus memuat rawî tsigah (dapat dipercaya), namun ditinjau dari sisi yang berbeda, kitab jenis ini bersifat umum, karena tidak dikhususkan pada rawî dari kitab-kitab tertentu. Contoh kitab al-rijâl al-tsiqât antara lain al-Tsiqât karya Muhammad bin Hibbân atau yang masyhur dengan Ibn Hibbân (w. 354 H). Bila diperhatikan, banyak ulamâ' setelah Ibn Hibbân yang bereferensi pada kitab Tsiqât-nya yang terdiri dari 9 juz ini. Ibn Hajar, contohnya, dalam kitab Tahdzîb al-Tahdzîb, secara konsisten dia berkomentar atas seluruh rawî yang tercakup dalam kitab Tsiqât, rawî̀ tersebut disebut oleh Ibn Hibbân dalam kitab Tsiqâtnya. Kitab Tsiqât Ibn Hibbân disusun berdasarkan huruf mu jam (urutan huruf Arab) dan terbagi ke dalam tiga bagian, yakni: (1) Biografi para sahabat, (2) biografi tâbi în, (3) biografi atbâ al-tâbi în. ${ }^{37}$

Ibn Hibbân menjelaskan bahwa "seluruh syaykh yang aku sebut dalam kitab ini dapat dipercaya dan riwayatnya dapat dijadikan $\underline{h} u j j a h$, apabila di dalam riwayatnya tidak terdapat lima hal berikut": (1) Jika di atas syaykh yang kusebut dalam kitabku adalah syaykh yang dla îf; (2) jika di bawah syaykh yang kusebut merupakan rawî yang lemah, maka Haditsnya tidak dapat dijadikan hujjah; (3) jika riwayatnya merupakan riwayat mursal; (4) jika sanad-nya munqati'; (5) jika di dalamnya terdapat rawî mudallis yang tidak terdapat penjelasan bahwa dia pernah mendengar khabar yang diriwayatkan. ${ }^{38}$

Sebagian orang menuduh Ibn Hibbân sebagai orang yang tasahhul atau menggampangkan menilai tsiqah (dapat dipercaya) rawî yang seharusnya berhak untuk di-jarh (dikritisi). Menurut Laknawî, kritikan tersebut lemah dan tidak beralasan, karena Ibn Hibbân termasuk ulamâ' yang sangat keras (mutasyaddid), bahkan terkesan berlebihan dalam men-jarh rawî, bagi ulamâ' yang seperti itu

\footnotetext{
${ }^{35}$ Muslim, al-Kunyah wa al-Asmâ', juz I (Madinah: Jâmi ah al-Islâmiyah, 1404 H.), hlm. 86

36 Kitab-kitab rijâl yang khusus memuat para rawî dengan kualitas khusus, seperti rawî yang tsiqah atau dla îf

37 Muhammad `Abd al-Hay al-Laknawî, al-Raf u wa al-Takmîl, (pentahqiq) `Abd alFattâh Abû Guddah (t.tp.: Dâr al-Aqshâ li al-Nasyr wa al-Tawzî', 1987), hlm. 332-333 38 Sebagaimana dikutip al-Laknawi, al-Raf $u$, hlm. 333-334
} 
Arif Wahyudi

keadaannya, maka mustahil apabila dia mutasahhil dalam men-ta 'dîl rawî (menilai seorang rawî dapat dipercaya). ${ }^{39}$

Kitab sejenis ini, antara lain adalah Siyar A lâm al-Nublâ' karya al-Dzahabî (w. $748 \mathrm{H}$ ) yang memuat informasi mengenai para intelektual Muslim dari mulai dia menulis kitab ke atas. Pengguna kitab yang terdiri dari 23 juz ini tidak akan mendapatkan sembarang rawî di dalamnya kecuali rawî̀ tersebut merupakan seorang intelektual. Kitab lainnya adalah Tadzkirah al- $\underline{H} u f f a ̂ d ~ k a r y a$ Muhammad bin Thâhir bin al-Qaysarânî, memuat tentang para rawî masyhur dari setiap thabaqat-nya. Kemudian, Târîkh Asmấ al-Tsiqat karya `Amr bin Ahmad Abû Hafsh al-Wâ'izh (w. 385 H), dan lain-lain dari kitab rijâl al-tsiqât.

\section{Kitab-kitab al-Rijâl al-Dlu'afầ}

Kitab rijâl al-dlu afầ merupakan kebalikan dari kitab rijâl altsiqât, yaitu kitab-kitab yang secara khusus memuat biografi rawî dla îf (lemah) namun sebagaimana jenis kitab sebelumnya, dari sisi yang lain kitab ini bersifat umum karena tidak dikhususkan pada rawî dari kitab tertentu.

Di antara kitab-kitab al-dlu 'afâ' adalah Mizân al-I'tidâl fî̀ Naqd al-Rijâl karya al-Dzahabî (w. 748 H). Kitab ini ditulis setelah kitab alMughnî fì al-Dlu afầ yang juga merupakan karya al-Dzahabî. Kitab alMughnî sendiri sesungguhnya merupakan kompodium dari kitabkitab Dlu 'afâ' sebelumnya, semisal al-Dlu 'afâ' Ibn Ma'în, al-Bukhârî, Abû Zar`ah, Abî Hâtim, al-Nasâ'î, Ibn Huzaymah, al-Uqaylî, Ibn `Adî, Ibn Hibbân, al-Dûlî, al-Khatîb dan Ibn al-Jawzî. Oleh karena itu, kitab tersebut dinamakan al-Mughnî fì al-Dlu'afầ karena diharapkan para pengkaji Hadits cukup melihat kitab itu untuk mengetahui para rawî dla îf. Dalam kitab ini al-Dzahabî memberikan komentar di beberapa tempat yang terpisah-pisah. ${ }^{40}$

Kitab Mizân al-I tidâl fî Naqd al-Rijâl sendiri merupakan

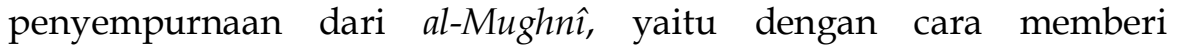
tambahan yang sebagian besar berasal dari kitab al-Kâmil fi al-Dlu 'afâ'

\footnotetext{
${ }^{39}$ Ibid., hlm. 335

40 Al-Dzahabî, al-Mughnî, Maktabah al-Alfiyah li al-Sunnah al-Nabawiyah, juz I (Amman: Markaz al-Turâts li Abhâs al-Hâsib al-Âlî, 1999), hlm. 5
} 
karya Ibn Ma 'în. ${ }^{41}$ Al-Dzahabî dalam menyusun kitab ini menggunakan sistematika tertentu, semisal: (1) Menyusun biografi rawî dengan huruf mu jam (sesuai dengan urutan huruf Arab); (2) memberikan tanda terhadap para rawî kutub al-sittah, al-Bukhârî dengan huruf $\dot{\tau}$, Muslim p, Abû Dawûd د, Tirmidzi ت, Nasa'i w, Ibn Mâjah ق., apabila si rawî̀ digunakan bersama oleh al-Bukhârî dan Muslim memakai rumus $\varepsilon$, sedangkan tanda bagi rawî yang digunakan sunan yang empat, yaitu عو Mizân al-I tidâl tidak mutlak seluruhnya dla îf, namun ada beberapa rawî̀ yang dinilai al-Dzahabî tsiqah, dia memasukkannya hanya karena si rawî̀ dikategorikan oleh ulamâ' sebelumnya dla 'îf dan dimuat ke dalam kitab dlu 'afâ' mereka; (4) menurut al-Dzahabî, kriteria rawî yang dia muat dalam kitab dla îf- nya ialah para rawî pembohong yang sengaja memalsu Hadits, dituduh sebagai pemalsu Hadits, suka berbohong saat berbicara, dituduh berbohong, cacat dalam kehidupan beragama maupun moralnya, majhîl, ${ }^{42}$ ahl al-bid ah dan terakhir lemah hafalannya. Namun menurutnya, rawî dalam kategori terakhir (lemah hafalan), riwayatnya dapat diterima jika terdapat penguat dari rawî lain yang tsiqah, asalakan bukan riwayat mengenai aqidah maupun halal dan haram. ${ }^{43}$

Kitab Mizân al-I'tidâl tersebut lalu diringkas oleh Ibn Hajar (w. $852 \mathrm{H})$ dalam karyanya Lisân al-Mizân. Ibn Hajar di dalam ringkasannya tidak memasukkan rawî yang telah termuat dalam Tadzîb al-Kamâl. Sebaliknya, dia pun memasukkan beberapa rawî bermasalah yang luput dari pengamatan al-Dzahabî. Menurut Ibn Hajar, dia memberikan tambahan kata إنتهى di akhir komentar alDzahabî, sebagai tanda bahwa kalimat setelah kata tersebut merupakan komentarnya sendiri. ${ }^{44}$

\section{Kitab-kitab al-Rijâl Makhsûshah}

Kitab al-Rijâl Makhsûshah adalah kitab rijâl yang memuat informasi khusus rawî dari kitab-kitab tertentu, namun dari sisi

\footnotetext{
41 al-Dzahabî, Mizân al-I tidâl fî Naqd al-Rijâl, juz I (Beirut: Dâr al-Kutub al-'Ilmiyah, 1995), hlm. 109.

42 Rawî yang tidak teridentifikasi biografinya (misterius)

43 al-Dzahabî, Mizân al-I tidâl, juz I, hlm. 113-114

${ }^{44}$ Ibn Hajar, Lisân al-Mizân, juz I (Beirut: Mu'assasah al-A lamî li al-Mathbû' în, 1986), hlm. 3
} 
Arif Wahyudi

kualitas para rawî, kitab-kitab jenis ini bersifat umum, yaitu mencakup rawî tsiqah maupun dla îf. Di antara karya yang monumental dari kitab-kitab-kitab jenis ini, antara lain Tahdzîb alTahdzîf karya Ibn Hajar (w. 852 H). Karya Ibn Hajar ini merupakan ringkasan dari kitab Tahdzîb al-Kamâl fí Asmâ' al-Rijâl karya Abû alHajjâj Yûsuf al-Zâkî al-Mîzî (w. $742 \mathrm{H}$ ), yang merupakan rujukan utama bagi biografi rawî yang ada dalam al-Kutub al-Sittah. Karya alMîzî ini banyak dikaji oleh para ulamâ', salah satu yang terbaik adalah Tahdzîb al-Tahdzîb, kitab ini lalu menjadi rujukan wajib setelah masa Ibn Hajar. Sedangkan Tahdzîb al-Kamâl tersebut, juga merupakan ringkasan dari kitab a-Kamâl fî̀ Asmấ al-Rijâl karya Abû Muhammad 'Abd al-Ghanî ibn Abd al-Wâhid ibn Surûr al-Muqaddasî.

Prinsip yang digunakan Ibn Hajar dalam meringkas, bahwa dia tidak akan pernah menghapus rawî yang telah ada dalam Tahdzîb al-Kamâl, yang terjadi justru Ibn Hajar menambahkan beberapa rawî jika si rawî tersebut memiliki kriteria yang sesuai dengan syaratnya. Jika terdapat rawî yang tidak meriwayatkan darinya kecuali satu orang, maka Ibn Hajar akan berusaha mencari satu orang lagi yang meriwayatkan darinya, agar predikat majhîl ayn lepas dari rawî tersebut. Namun, apabila terdapat rawî yang terkadang jumlah gurunya mencapai seribu orang, maka dia akan meringkasnya dan berusaha untuk tidak merubah presepsi orang terhadapnya. Terkadang dia menambah atau bahkan mengurangi agar kalimat semula dapat lebih jelas. Dalam pemberian tambahan tentang informasi rawî, Ibn Hajar mengawalinya dengan kata-kata ق. 45

Kitab Tahdzîb al-Tahdzîf lalu diringkas lagi oleh Ibn Hajar sendiri dalam Taqrîb al-Tahdzîb. Jika pengguna kitab rijâl terkadang bingung dengan komentar ulamâ' yang berbeda dalam satu rawî, maka hal tersebut akan berbeda jika yang digunakan adalah kitab Taqrîb. Yang demikian terjadi karena kitab tersebut hanya memuat kesimpulan Ibn Hajar dari penelitiannya terhadap para rawî Kutub alSittah. Kitab ini menurut sebagian orang, merupakan puncak dari keilmuan Ibn Hajar dan ijtihad terakhir dalam menentukan kualitas rawî Kutub al-Sittah karena diselesaikan dua tahun menjelang wafatnya.

${ }^{45}$ Ibn ㅂajar, Tahdzîb al-Tahdzîb, juz I (Beirut: Dâr al-Fikr, 1984), hlm. 4-5 


\section{Kitab-kitab al-Rijâl al-Buldân}

Melacak ketersambungan suatu sanad agar lebih akurat dapat dilakukan dengan berbagai metodologi maupun perspektif. Di samping melalui tahun lahir dan tahun wafat, ketersambungan itu dapat dilacak pula melalui kitab-kitab buldân maupun kitab-kitab thabaqât. Contohnya, bila dalam suatu sanad terdapat rawî̀ A yang berasal dari Baghdad meriwayatkan dari rawî $\mathrm{B}$ yang berasal dari Damaskus, untuk melacak ketersambungannya haruslah dilihat dalam kitab-kitab buldan ini, jika si A pernah ke Damaskus atau B pernah ke Baghdad, maka ketersambungannya menjadi mungkin. Namun, bila tidak maka dapat dipastikan bahwa terdapat masalah dalam sanad tersebut. Di antara kitab-kitab buldân tersebut ialah Târîkh Damsyik karya Ibn `Asyâkir (w. $571 \mathrm{H}$ ). Kitab ini diawali dengan pemaparan tentang peradaban negeri yang dibahas yaitu Damaskus, dimulai dari zaman penyusunnya ke atas, baik hukum, ekonomi, sungai, tempat ibadah, dan lain sebagainya. Setelah pemaparan tentang berbagai hal mengenai negeri tersebut barulah kemudian penyusun kitab memaparkan tentang orang-orang yang tinggal maupun pernah berkunjung ke Damaskus, baik para pemimpin negeri, para gubernur, para ahli fiqih, para qâdlî (hakim), ulamâ' dan tentu saja para rawî Hadits. 46

Di antara kitab-kitab buldân lain ialah Târîkh Baghdâd karya alKhathîb al-Baghdâdî (w. 463 H), Thabaqât al-Muhadditsîn bi Asbahân karya Ibn Hayyân (w. $369 \mathrm{H}$ ) yang memuat para sahabat dan tâbi în yang pernah berkunjung ke Asbahân. Ketiga kitab ini bila dicermati memiliki kemiripan dalam metodologi penyusunannya hanya negeri yang menjadi dasar penyusunannya berbeda. Karya lain di bidang ini, antara lain, adalah al-Istî 'âb fî̀ Ma 'rifah al-Ashâab karya Ibn `Abd alBârr yang secara khusus memuat tingkatan para sahabat, al-Thabaqât karya al-Nasâ'î, dan lain-lain.

\section{Kitab-kitab al-Rijâl al-Tabaqât}

Thabaqât yang secara bahasa dapat berarti tingkatan. Menurut Subhî Shâlih ${ }^{47}$ ialah sekumpulan orang yang sebaya dalam usia dan dalam menemukan guru. Sebagaimana telah disebutkan sebelumnya, bahwa kitab-kitab thabaqât ini dapat menjadi pilihan untuk melacak

46 `Alî Syîrî, Muqaddimah Târîkh Damsyiq (Beirut: Dâr al-Fikr, tth.), juz I, hlm. 28

47 Shalih, Membahas Imu-ilmu Hadits, hlm. 323 
Arif Wahyudi

ketersambungan sanad suatu Hadits. Di antara karya-karya tersebut ialah al-Thabaqât al-Kubrâ karya Muhammad ibn Sa 'ad ibn Manî (w. $230 \mathrm{H}$ ) yang populer dengan Ibn Sa`ad. Kitab ini disusun dengan metode periwayatan yang memuat informasi para ahli Hadits dan para pemilik nasab pada masa nabi saw., tâbi î̀n dan masa hidupnya kemudian ditutup dengan thabaqât perempuan. Sebelum hal tersebut, karya ini diawali dengan informasi para nabi yang berputra utusan Allah swt., semisal Idrîs, Nûh, Ismâ'il, dan sebagainya.

Dalam membagi tingkatan sahabat, Ibn Sa`ad membagi kepada para sahabat Muhajirin yang ikut perang Badar, sahabat Anshar yang ikut perang Badar, sahabat yang lebih dulu masuk Islam dan ikut hijrah ke Habasyah, perang Uhud dan sebagainya, sahabat yang memeluk Islam sebelum Fath Makkah serta sahabat yang masuk Islam setelah Fath Makkah. ${ }^{48}$

\section{Penutup}

Kitab-kitab induk Hadits adalah kitab-kitab yang disusun oleh mukharrij Hadits dengan sanad yang bersambung pada generasigenerasi di atasnya sampai kepada nabi saw. Tanpa mengutip dari kitab lain dan ditulis sebelum abad kelima hijriah. Kitab-kitab induk ini sangat beragam dan disusun dengan sistematika yang bermacammacam, mulai muwattha', musnad, Shaĥîh, jâmi', sunan dan lain-lain. Merujuk kepada kitab-kitab tersebut sebenarnya tidaklah sulit dengan sistematika yang telah dibuat penyusunnya, yang diperlukan hanya melihat kepada bab-bab dalam kitab tesebut.

Pada abad kelima penulisan Hadits telah mencapai batas maksimalnya, kajian Hadits kemudian beralih kepada usaha untuk mengelaborasi kitab-kitab induk di atas. Seperti men-syarh yang dapat dikatakan menafsirkan dalam kajian al-Qur’an, yaitu menjelaskan makna-makna yang sulit dalam Hadits, menjelaskan pendapat ulamâ' mengenai kandungan hukum dalam matn Hadits atau menjelaskan kondisi sanad dan kontroversi mengenainya. Cukup aneh dalam kajian Hadits, jika memaknai Hadits tanpa melihat ke dalam kitab syarh. Sebagaimana diketahui bahwa nabi saw. adalah orang yang paling fasih dalam berbahasa Arab, bahasanya padat dengan makna yang maksimal. Oleh karena itu, perlu kiranya syarh

48 Ibid., hlm. 317- 319 
Hadits yang disusun para ahli pada bidang ini untuk mengungkap makna yang maksimal dari setiap hadis tersebut.

Kitab penghimpun Hadits salah satu yang banyak ditulis pula oleh para muhaddits belakangan, dengan menghimpun Hadits-hadts bertema tertentu dari berbagai macam kitab induk Hadits. Kitab-kitab ini ditulis dengan lebih ringkas dan tanpa menuliskan sanad HaditsHaditsnya, sistematika pembabannya dibuat lebih baik dan sistematis. Dengan corak seperti tersebut, maka kitab-kitab ini menarik minat banyak pengkaji agama, namun kepopuleran kitabkitab ini berimbas pada kekeliruan persepsi bahwa kitab-kitab tersebut adalah kitab-kitab induk Hadits. Sehingga penukilan terhadap suatu matn Hadits tidak dirujuk ke kitab yang seharusnya yaitu kitab-kitab induk Hadits, tetapi justru ke kitab-kitab penghimpunan.

Untuk mengkaji tentang para periwayat Hadits, maka perlu dirujuk kitab-kitab rijâl, bila tidak diketahui perihal periwayat, maka sebaiknya melacak ke kitab-kitab rijâl umum, jika periwayatnya diduga merupakan periwayat yang tsiqah, atau dla'îf ke kitab rijâl khusus tsiqah atau khusus dla' $\hat{f} f$, namun apabila hendak memastikan seorang periwayat benar-benar mendengar dari guru atau meriwayatkan ke muridnya sedangkan mereka berbeda daerah maka dilacak di kitab-kitab buldan. Bila ingin melacak melalui generasi si periwayat maka kitab-kitab thabaqat-lah yang paling tepat.

\section{Daftar Pustaka}

'Asqalânî, Ibn Hajar al-. Muqaddimah Fath al-Bârî. Beirut: Dâr alMa`rifah, 1980.

‘Asqalânî, Ibn Hajar al-. Hâdi al-Syâri`. Kairo: t.p., t.t.

Baghdâdî, Ahmad bin Alî Abû Bakr Khatîb al-. Târîkh al-Baghdâdî. Beirut: Dâr al-Kutub al-'Ilmiyah, tth.

Bukhârî, al-. al-Kunâ li al-Bukhârî. Beirut: Dâr al-Fikr, tth.

Bukhârî, al-. Târîkh al-Kabîr, http://www.alsunnah.com, Maktabah alSyâmilah terbitan ke-II, http://www.shamela.ws,

CD al-Maktabah al-Alfiyah li al-Sunnah al-Nabawiyah. Yordania: Markaz al-Turâts, 1999)

Dosen Tafsir Hadits IAIN Sunan Kalijaga Yogyakarta, Studi Kitab Hadis. Yogyakarta: Teras, 2003. 
Arif Wahyudi

Dzahabî, al-. al-Mughnî, Maktabah al-Alfiyah li al-Sunnah al-Nabawiyah. Ammân: Markaz al-Turâts li Abhâs al-Hâsib al-Âlî, 1999)

Dzahabî, al-. Mizân al-I tidâl fî Naqd al-Rijâl (Beirut: Dâr al-Kutub al'Ilmiyah, 1995.

Dzahabî, al-. Siyar A 'âm al-Nubalâ. Beirut: Mu'assasah al-Risâlah, 1413 $\mathrm{H}$.

Hajar, Ibn. Lisân al-Mizân (Beirut: Mu'assasah al-A'lamî li alMathbû'în, 1986.

Hajar, Ibn. Tahdzîb al-Tahdzî̉. Beirut: Dâr al-Fikr, 1984.

Hâkim, al-. al-Mustadrak Alâ al-Shahlihhain, (pentahqiq) Mustafâ Abd alQadir `Athâ. Beirut: Dâr al-Kutub al-'Ilmiyah, 1990.

Hanbal, Ahmad bin. Musnad Ahmad. Kairo: Muassasah Qurthubah, tth.)

Khûlî, Muhammad Abd al-Azîz al-. Miftah al-Sunnah wa al-Funûn alHadîts. Beirut: Dâr al-Kutub al-'Ilmiyah, 1980.

Laknawî, Muhammad 'Abd al-Hay al-. al-Rafu wa al-Takmîl, (pentahqiq) `Abd al-Fattâh Abû Guddah. ttp.: Dâr al-Aqshâ li alNasyr wa al-Tawzî̀, 1987.

Mâlik, Anas bin. al-Muwattha', (pentahqiq) Muhammad Mushtafâ alA`zhamî. ttp: Muassasah Zaid ibn Sulthân al-Nahyân, 2004.

Muslim. al-Kunyah wa al-Asmấ. Madinah: Jâmi`ah al-Islâmiyah, 1404 $\mathrm{H}$.

Muslim. Shahîh Muslim. Beirut: Dâr al-Fikr, 1988.

Nawâwî, Abû Zakariya Yahyâ bin Syaraf al-. Syarh al-Nawâwî̀ 'Ala Shahîh Muslim. Beirut: Dâr Ihyâ' al-Turâts al-'Arabî, t.t.

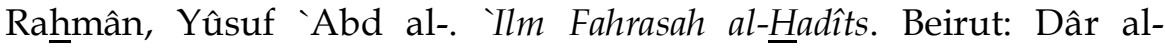
Ma`rifah, 1986.

Shâlih, Subhî. Membahas Imu-Ilmu Hadits, terj. Tim Pustaka Firdaus. Jakarta: Pustaka Firdaus, 2009.

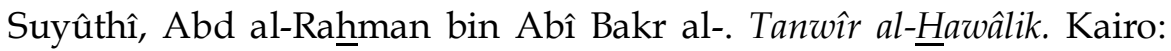
Maktabah al-Tijâriyah Kubrâ, 1969.

Syîrî, `Alî. Muqaddimah Târîkh Damsyiq. Beirut: Dâr al-Fikr, t.t.

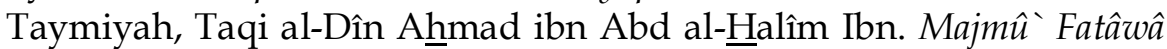
li Ibn Taymiyah. T.tp: Dâr al-Arabiyah, t.t.

Zahwu, Abû. al-Hadîts wa al-Muhadditsûn. Kairo: Maktabah alSalafiyah, t.t.

Zuhri, Muh. Hadits Nabi Telaah Historis dan Metodologis. Yogyakarta: PT. Tiara Wacana, t.t. 